\title{
'This is the White Man's Day': The Irish, White Racial Identity, and the 1866 Memphis Riots
}

\author{
Barrington Walker ${ }^{1}$
}

I

May 1, 1866 marked the beginning of a series of riots that rocked south Memphis for three days. The principal actors in these skirmishes were decommissioned black Union troops, newly emancipated African American civilians, and a cross section of members of the city's Irish community. By the time the commanding officer in Memphis - General George Stoneman - was able to restore the peace, the south side of Memphis lay in ruins. The city's African American community in particular bore the brunt of the destructive force of the riot. The effects of the riot on Memphis' African American community are well documented in the House of Representatives committee report of the ThirtyNinth Congress. On the basis of the testimony of a hundred and seventy witnesses, the committee was able to conclude that forty-six African Americans were murdered (as opposed to only two whites), seventy five African Americans were wounded, five African American women were raped, one hundred African Americans were "maltreated," one hundred were robbed, ninety-one homes in the black community - along with four churches - were burned, and twelve school houses destroyed. In total \$130,981 worth of damage was inflicted upon the African American community as well as on various federal government properties and agencies. ${ }^{2}$

The existing historiography of the Memphis riot has tended to focus mainly on themes such as "interracial hostility" and the role of white political leaders in stirring up anti-black sentiment; the rapid demographic shifts that took place in Memphis, and the resulting alteration in race relations; rioters influenced by a long history of ritualized collective violence towards perceived "immediate threats" to their communities which, in the end, inexorably pushed the city towards modernization; and, finally, the historic importance of Memphis as a "centre for the recruitment and administration of black military units" and the related powerful and strategic position occupied by black soldiers - particularly in light of their importance to former slaves attempting to reposition themselves in a hostile, racist postbellum southern city. ${ }^{3}$

Clearly the conditions contributing to the outbreak of the riot were varied, complex, and must be looked upon within the context of the profound social, economic, political, and demographic transformations that shaped the Reconstruction era South as a whole and took on particular manifestations in 


\section{Left History 5.2}

Memphis. In conjunction with these elements, however, we must also examine ideological ${ }^{4}$ aspects of the post-war era in Memphis which have hitherto been unsatisfactorily explored; namely, the attempts of one of the most despised communities in Memphis - the Irish - to assert the privilege and power of white racial identity.

Though the Memphis riots have been the subject of considerable scholarly attention, none of these studies benefit from the critical insights of the relatively newly emergent scholarship on the construction and historicity of "whiteness." I will argue that the major ideological element of the 1866 Memphis riot was a manifestation of the collective frustration of the Irish of Memphis resulting from the fragile and dissolute status of their whiteness. ${ }^{6}$ Through the use of collective violence, the Irish sought to shore up the fragile status of their whiteness, and hence solidify their tenuous hold on power in the city. The dissoluteness of Irish whiteness, due to the fact that for roughly a decade prior to the Memphis riots, the white racial status of the Irish was not at all certain, engendered a complex discursive/rhetorical construction of Irish "racial" subjectivity. It placed them simultaneously inside and outside of the leaky category ${ }^{7}$ of whiteness, thus creating an incongruity between the Irish communities' newly elevated position within the city and the degraded place they occupied in the imagination of elite whites and, at least to some extent, African Americans. As other scholars have pointed out, the evidence suggests that economic competition, while important, cannot alone explain the hostility between Memphis' black and Irish communities during this period. In fact, most of the Irish engaged in this riot were not members of the the degraded labouring classes, but from a cross-section of socioeconomic strata consisting of Irish business and civil leaders, as well as a few "common labourers." Thus, most of the Irish participants in the riot did not fear direct economic competition from African Americans. The Irish of Memphis recognised that despite the widespread contempt in which they were held, the one thing they had that African Americans did not was "white" skin. They also realised, like other immigrant groups which followed them, that what was often necessary in claiming the "prize" or "psychological wage" of whiteness was an open and violent rejection of blackness; though admittedly, this rejection of blackness was by no means unequivocal. The Irish community in Memphis asserted their claim to white skin privilege by targeting the most serious threats to their newly achieved civic political ascendancy, and, thus, the mob systematically targeted the most powerful symbols of African American autonomy and agency. The terror unleashed upon black homes, schools and churches was not only - in the words of one author - a response to the threat posed to the "integrity of their community"8 but more importantly, an outward manifestation of psychocultural angst on the part of a despised group which desperately wanted to identify with the dominant culture, and to symbolically stake its own claims for white supremacy. 
The 1866 Memphis riot was very much contingent upon the profound structural forces - economic, political, social and demographic - which dramatically changed the city during Reconstruction. Two major groups in particular placed an indelible stamp on this city during its growth from a small antebellum town to a postbellum southern city: the African American and Irish communities.

The impact of African Americans upon Memphis in the aftermath of slavery was profound, and has been described by one scholar as no less than a "demographic revolution imposed upon Memphis by the events of the Civil War." The development of a discernible urban black presence in Memphis was the gradual - and arguably unintended - result of federal government policy in Tennessee during the war. With the arrival of Union troops in Tennessee as early as 1862, federal government policy towards African Americans grew out of pragmatism rather than altruism, and reflected a mixture of racist attitudes and crass opportunism on the part of government and military policy makers.

By January of 1863, the decision was made to consolidate the various small "contraband camps" located throughout the Mississippi Valley into areas which were centrally located and generally regarded as easily defensible. Memphis was chosen as one of these sites, and thus, large federally occupied towns like Memphis came to offer African American "contrabands" the best opportunity to secure their freedom. Memphis was one of two Tennessee urban centres (Nashville was the other) which contained the largest populations of fugitive slaves in the state. By March of the same year, under the direction of Chaplain Fiske, Superintendent of the Contrabands in West Tennessee, 1,236 African Americans joined the 3,000 blacks that had resided in Memphis prior to the Civil War. In addition, approximately 2,500 freedmen existed in three contraband camps outside the city limits. ${ }^{10}$

These newly arrived African Americans placed an indelible stamp on Memphis. They forever changed the composition of the African American community as well as relations between the African American community and the larger population. As more and more freedmen and freedwomen poured into the city, the existing structures of the the Union Army proved inadequate. The policy of the Union Army was to provide rations to African Americans in return for their labour power, and thus, the army had no guidelines in place to assist those unable to work. The inability of the Union Army to deal with the complex problems created by large numbers of freedmen and freedwomen created a peculiar mix of anxiety, contempt, and paternalism from Union officers who sought to find ways of controlling what they perceived to be a population of "lazy and indigent Negroes."11 In an April 1863 memorandum to his superiors, Chaplain John Eaton, General Superintendent of the Contrabands Department of Tennessee lamented:

Negroes, in accordance with the Acts of Congress, [feeling] free in coming 


\section{Left History 5.2}

within our lines, circulated much like water; the task was to care for $\&$ render useful. They rolled like eddies around military posts; many of the men employed in accordance with Order No 72, District West Tennessee, women and children largely doing nothing but eating and idling, the dupes of vice and crime, the unsuspecting sources of disease. ${ }^{12}$

The anxiety and contempt that Eaton felt towards towards the urban contrabands is clearly evident from this excerpt, and this anxiety was undoubtedly exacerbated by Brigadier General Lorenzo Thomas' decision in September, 1863 , to make Memphis the centre of recruitment and administration for black troops in Tennessee. Thomas' initiative put an even greater strain on a city already reeling from the effects of the settlement of thousands of contrabands, while it set the stage for an emerging solidarity between black troops and the larger black community in Memphis. The strong bond that was created between black Union soldiers in Memphis and the black community is reasonably well documented in the literature, and, for one scholar, as mentioned above, constitutes the single most important aspect of his interpretation as he argues that "[b]lack soldiers, whose uniform conferred upon them the authority of the victorious Union Army, occupied a particularly strategic and powerful position within the larger community of black people living in Memphis, and were prominent in the efforts of the southern slaves to redefine their position within southern society."13

While the emerging solidarity between Memphis blacks and the black Union troops stationed in Memphis is not the main thrust of the argument presented in this article, it does warrant some attention. When army officials began to concern themselves with the alleged "problem" of black "idleness" and "vagrancy" in and around the contraband camps in Memphis, the solution proposed was the relocation of the wives and children of black troops. ${ }^{14}$ The efforts of the army to carry out this relocation policy ultimately ended in failure. The military experienced a great deal of resistance on this issue; indeed, a near riot began when T. A Walker, Superintendent of Freedmen in Tennessee, sent in a detailed guard of twelve men and "all the teams at [his] disposal" 15 to relocate black soldiers' families to plantations on President's Island. These families refused to be moved out of Memphis, and instead engaged in various types of resistance. Walker complained that rather than comply with orders, Memphis blacks instead "[lock] their doors, and run to their husbands in the various military organizations for protection. The husbands swear their families shall not be moved to the Island and in some instances have come out under arms to prevent it." 16 These forms of resistance did win a partial victory for black soldiers and their families as the army later issued an order declaring that all black troops who were "legitimately" married, and did not desire to have their families removed from the city, could present marriage certificates to the commanders of their respective companies. ${ }^{17}$ 
The President's Island incident was not the only evidence of the emerging solidarity between black troops and the black community. By the fall of 1865 , the Union Army's desire to relocate "surplus" blacks out of Memphis was as strong as ever. General Dudley (who at this time was the head of the Freedman's Bureau in Memphis) came under pressure from the military leadership, planters, and other white citizens to move blacks out of the city and on to plantations to find work. ${ }^{18}$ In October, 1865, Dudley issued an order stating that the streets were to be patrolled by soldiers from Fort Pickering; these soldiers were given the authority to arrest "vagrants" and negotiate labour contracts between vagrant blacks and white Memphis planters. ${ }^{19}$ In December of that year, however, Dudley was removed from his position due to an investigation which revealed that many blacks had been bound over to planters by force. In addition, it was also discovered that many of Dudley's officers had been bribed by planters to supply them with blacks picked up by army patrols. ${ }^{20}$

The army attempted yet another relocation program under the leadership of Dudley's successor, Davis Tillson, who, similar to his predecessors, devised a plan to relocate approximately 6,000 unemployed blacks out of Memphis to work on plantations in west Tennessee, northern Mississippi, and eastern Arkansas. ${ }^{21}$ Massive arrests of unemployed black men were subsequently conducted in and around the city. Freedmen were charged with a range of offences by the Freedman's Bureau: selling cotton without a licence, operating a hack on a sidewalk, disorderly conduct, fighting, stealing, cursing, and wife beating. ${ }^{22}$ Those who had difficulty paying their fines were sent to work for whomever paid for them. These benefactors were, in most cases, opportunistic white planters.

Despite the numerous attempts at relocating Memphis blacks, African American soldiers fought vigorously to undermine the efforts of the Freedman's Bureau. Black soldiers frequently campaigned against the army's efforts by instructing Memphis blacks to simply disregard white men's orders. Tillson complained that "coloured soldiers interfere with [the lives of Memphis' blacks] and tell free people that the statements made to them by the [white] soldiers sent for the purpose are false, thereby embarrassing the operations of the Bureau."23 Despite orders to cease obstruction of the relocation program, black troops persisted and further demonstrated their militancy by refusing to transport blacks to railroad depots in Memphis and Charleston for shipment out of the city. ${ }^{24}$

\section{III}

Newly emancipated African Americans were not the only group to make a significant impact on the demography of mid nineteenth century Memphis. Similar to the old "free black" community, the Irish had a rather long history in Memphis. A considerable number of the Irish had historically enjoyed prominent positions in the social and political life of early-nineteenth-century 


\section{Left History 5.2}

Memphis. Indeed, for most of the antebellum period, the most visible members of the Irish community (whom, to be more precise, were principally Protestant Irish) were members of the ranks of the petty bourgeoisie: property holding professionals, tradesmen and craftsmen. ${ }^{25}$

The composition of Memphis' Irish community began to change after 1850. Between 1850 and 1860 , four railway tracks were constructed in the Memphis area. Southern railway companies had traditionally relied on slave labour to build railroad tracks, and thus, labour agreements were often reached between railway companies and local planters whereby in exchange for the use of slave labour on railroad gangs, planters were issued railway stocks. ${ }^{26}$ However, in Kentucky and Tennessee, the practice of utilising slave labour was abandoned in favour of of hiring Irish labourers from northern cities. The dangerous tasks involved in building railroads often resulted in severe injury or loss of life to slaves. The peril in which railway companies placed valuable slaves was especially important after 1853. In 1853 the Supreme Court of Alabama ruled that those who hired out slave labour and employed slaves to perform tasks which were "contrary to the ordinary pursuits for which slaves are used" would be held fully liable for any damages sustained to the slave. ${ }^{27}$ Thus, due to the perverse and inherently contradictory nature of chattel slavery in the American South, the lives of the "white" working-class Irish were deemed less valuable than the lives of enslaved African Americans. In essence it became more profitable for railway companies to employ Irish wage labourers rather than risk the lives of coveted chattel slaves. The decision of the Alabama court was to have a profound effect on the city of Memphis.

Between 1850 and 1860, the Irish population in Memphis increased from 9.9 to 23.2 percent of the total population of Memphis. ${ }^{28}$ By 1860, 5,242 Irish immigrants resided in Memphis, a five fold increase from the scant 876 found in the city ten years earlier. An incident that took place in the summer of 1854 was illustrative of how this rapid increase in the Irish population - which was primarily from the ranks of the Irish-Catholic labouring class - influanced the sentiments of the greater native born white community in Memphis. On 18 August 1860, two hundred Irish labourers were scheduled to work on the Memphis and Ohio Railroad. A.B. Taylor, the mayor of Memphis at this time, ordered the militia to be on alert to "preserve the American way of life." Taylor alerted the militia in response to rumours that two hundred more Irish were to arrive in Memphis in the next few days and would remain in Memphis for several months while working on the Memphis and Ohio Railroad extension to Grenada. The Memphis Appeal denounced the mayor's actions, and in an editorial appeal urged the people of Memphis to let reason prevail over their prejudices:

The military should ground their arms, at least for the present unless they are prepared to become useful and fight the paddies with spade and shovel in 
building our railroads. Away with such humbugery and nonsense. Who feels cheap this morning? ${ }^{29}$

The reaction that was generated by a handful of Irish labourers coming to work on a Memphis railroad signalled a change in the white native born populations' perception of the Irish. It was a change that was indicative of the effect of the lowly socioeconomic status of the Irish migrants who flocked to Memphis during this period. In 1850, the vast majority of the Irish lived in the first ward of Memphis - the poorest ward in the city. ${ }^{30}$ By 1860 , the population of ward one had increased by 300 percent. However, even after ten years of steady migration to Memphis, a city that was booming in the late-antebellum era, the status of most Irish had changed very little. After a decade in Memphis, they still constituted half of the residents in the impoverished first ward. ${ }^{31}$ Two other factors are illustrative of the low social mobility of the Irish in Memphis prior to 1866 . First, in the antebellum South, where a city's wealth was measured by the number of taxable slaves its citizenry owned, most of the Irish resided in a ward that had the fewest number of slaves. Secondly, the 1850 census revealed that 77.8 percent of the Irish in the first ward were unskilled workers. ${ }^{32}$ By 1860 , this figure had changed little; 76.6 percent of all the Irish in Memphis were still members of the labouring class. ${ }^{33}$

Paradoxically, the low economic status of the Irish was not indicative of the considerable political clout they enjoyed en masse as a voting block after 1865 . The Disenfranchisement Act was pointed to by most contemporary observers as the reason for the transfer of political power to the newly arrived immigrants particularly the Irish. This act, which was passed on 5 June 1865 , limited the franchise to white men who demonstrated that they had been unconditionally loyal to the Union. Those who had helped the Confederacy in any way during the war were to be disenfranchised for a minimum period of fifteen years. ${ }^{34}$ Conversely, "loyal men" from other states who had either lived in Tennessee for six months, or were unwillingly forced into Confederate military service, and reaffirmed their loyalty to the Union in the presidential elections of 1864 or the congressional elections of 1865 , were granted the franchise. ${ }^{35}$

During the war, many Memphis citizens were ineligible to vote due to the rigorous loyalty oath mandated by Military Governor Andrew Johnson. In addition, there were many slaveholders who would not, or could not, take the oath due to the fact that an essential component of the oath was an endorsement of the Emancipation Proclamation. In 1866, the Disenfranchisement Act was amended. The amended act of 1866 made the right to vote even more difficult to exercise for many of Memphis' older residents. Those making a claim for the franchise had to provide evidence of their loyalty to the Union by presenting evidence in the form of two competent witnesses before the Office of the Commissioner. These witnesses were to be "known to the commissioner to have been themselves at all times unconditional Union men...personally acquainted 
with the person so claiming, and...they [must] verily believe that [the claimant] has not been guilty of any of the disqualifications...specially mentioned, subscribed by said witnesses and, filed in the office of said commissioner." ${ }^{36}$ Additionally, the claimant was required to to take an oath before the Commissioner of Registration. The oath required applicants to declare that they had never born arms against the United States for the purpose of aiding the rebellion, that they had never sought nor accepted any office under the "pretended authority of the so-called Confederate States of America," and had not given any voluntary support to any such Government or authority. Three groups were exempted from these provisions: all white citizens who had been honourably discharged from the United States army or navy after 1 January, 1862; those who qualified to vote in the 1864 Presidential elections, the "Ratification and Rejection" election in February of 1865, or the March 1865 legislative and gubernatorial elections; and all white citizens who had been appointed to any civil or military office by Andrew Johnson or Tennessee Governor William Brownlow. ${ }^{37}$ These requirements were rigidly adhered to in all state, country, district and municipal elections in Tennessee. Thus, within the city of Memphis in particular, these stringent requirements for suffrage allowed the Irish - one of Memphis' poorest and most despised groups — to in effect "hijack" the city for a brief moment in time.

In the 1865, mayoral elections, John Park was able to defeat William O. Lofland by a margin of 521 votes. Though Park was not born in Ireland, he was Irish by parentage and thus felt an affinity with Memphis' Irish labouring class; it was precisely the support of these Irish workers that in large measure ensured Park's victory. In addition to Park's election to the mayor's office, nine of the sixteen aldermen elected in Memphis were Irish and 67 percent of all elected and appointed offices were held by the Irish. Park's regime ushered in substantial changes to the character of Memphis' civil service, and nowhere were the Irish better represented than in two key civil institutions: the police and fire departments. By 1865,163 of Memphis' 180 member police force were Irish, as well as 86 percent of the city's firefighters ${ }^{38}$ - this later proved to be of crucial importance in light of the violent and incendiary nature of the riots. The political ascendancy of the Irish, along with the large and formidable presence of Irish workers who had acquired a new and fragile "respectable" working class status via Memphis' police force and fire department, was to have serious repercussions for the city's African American community.

\section{IV}

April 30, 1866 was the day the War Department set to muster all African American troops stationed in Memphis out of service. On this day, an incident occurred which was illustrative of the deep seated tensions between Memphis blacks and the predominately Irish police force. Indeed, a few witnesses main- 
tained that it was the actual beginning of the riots. That afternoon a skirmish erupted between three African American men and four Irish police officers which began with an exchange of harsh words, and ended with a physical battle in the middle of Causey street. One police officer was violently attacked with a stick, and, according to one observer, one of the blacks was hit so forcefully with an officer's pistol that the handle of the gun broke. After several minutes of fighting, both parties dispersed, each side threatening the other with further retaliatory violence. ${ }^{39}$

On the following day, Tuesday, 1 May, violence erupted in the south section of Memphis. On that afternoon, most of the black soldiers stationed in Memphis had received their back-pay and bonuses from the Union Army. While most of the soldiers by then either retired to their homes in South Memphis or in nearby counties or states, a few of the soldiers, having nothing better to do, decided to venture into the red light district near Fourth and South Streets. ${ }^{40}$ These men joined African American women and children in the street forming a crowd of about one hundred and fifty. It was a rather jovial gathering; the men drank whiskey while joking, singing, and generally entertaining onlookers. ${ }^{41}$

The behaviour at this gathering, however, was misconstrued as "disorderly" and "riotous" by the authorities. When police arrived on the scene, African American soldiers gathered on South Street and defiantly led the crowd in proclaiming: "Three cheers for Abe Lincoln, the Great Emancipator." To this a policeman nastily replied, "Your old father Abe Lincoln is dead and damned."42 The police arrested two men, and as the officers attempted to walk off with them they were surrounded by black solders who, in an attempt to prevent the police from leaving with their captives, fired their pistols into the air. The police, thinking that they were being fired upon, turned and began firing into the crowd of black soldiers and citizens. ${ }^{43}$

The result was a protracted exchange of gunfire between the police and black troops; this initial skirmish was indicative of much of what was to follow. By the time the conflict was resumed that night however, those whites engaged in the riot acted with near official sanction from the Union Army and city officials. Shortly after the initial outbreak of violence Sheriff Winters, Sheriff of Shelby county, and several others went to the office of General Stoneman and requested that Stoneman use the troops under his command to quell the disturbance. Stoneman declined the request and asked Winters if he had used "all means at his disposal" or indeed even "summoned a sheriffs' posse for that purpose." During this meeting, Stoneman also remarked that "the people of Memphis had been anxious to get rid of United States troops and were perfectly competent and capable of taking care of themselves." Stoneman preferred, therefore, to ensure that his intervention was absolutely necessary before calling Union troops into requisition. ${ }^{44}$

Later that day, Mayor Park sent a memorandum to Stoneman requesting that a force of two hundred Union soldiers be held ready to cooperate with the 


\section{$40 \quad$ Left History 5.2}

constabulary force of the city. ${ }^{45}$ Stoneman, in keeping with his laissez faire policy in matters he believed to be the responsibility of civil authorities, gave assurances that a small force of one hundred and fifty infantrymen would be made available to aid civil authorities only in the case of "extreme necessity." The determination of what constituted an "extreme necessity," however, was left up to Park and other local authorities. ${ }^{46}$

In addition to securing the complicity of local military officials, Mayor Park wasted little time in calling a special meeting of the Board of Aldermen. Park called this meeting just moments after the board had officially adjourned for the evening. ${ }^{47}$ It is clear that Park took these dramatic steps in order to whip up a state of panic and disorder among Memphis Aldermen. This is evidenced by the fact that it was the policy of the Memphis Board of Aldermen to meet on the first Tuesday of every month. ${ }^{48}$ As the mayor of Memphis, Park was certainly aware of the Board's policy and thus had no reason to call a special meeting aside from his machinations to legitimate an assault against Memphis' black community. The mayor's actions were especially suspect in light of the fact that the trouble that had erupted in South Memphis earlier that day had subsided several hours previously.

Park played his hand perfectly in that he was able to manufacture a climate of crisis which easily enabled him to persuade the Aldermen to grant him the authority necessary to halt the "riot" in South Memphis. At the commencement of this emergency meeting, Park read this prepared statement to the Board:

I find, as well as you and all the good citizens, that the disturbance between the blacks and the whites this evening requires prompt actions on our part. In the absence of proper military aid, therefore, please authorize me as Mayor, to secure such aid as may be required to quell and suppress the disturbance and I will do it. ${ }^{49}$

Assistant City Attorney General Bankhead, when called upon to instruct the Board on the issue of the legal duties and official powers of a Mayor in this time of crisis, stated that he thought that the Mayor would be justified in taking whatever steps he thought the emergency required. A resolution put on the table by Alderman Toof giving Park authorization to "preserve the public peace throughout the city" was promptly ratified. Shortly after, Park declared the doors of city hall closed and summoned all of the Alderman present to become part of a posse comitatus. ${ }^{50}$

A second round of skirmishes broke out that night at approximately ten o'clock; the main participants were African American soldiers, Sheriff Winters' police force, and a group of about fifty men. Several African Americans were shot and killed that night, and, in addition, black owned businesses, homes and buildings of the Methodist church were set on fire. ${ }^{51}$ The next morning, a small delegation representing the black troops of Memphis went to General Stoneman 
and requested that their weapons be reissued. In light of the circumstances, the soldiers' request was not an unreasonable one, but it was refused. The General's laissez-faire approach towards the riot, coupled with his decision to withhold weapons from those black soldiers who had compliantly (although perhaps foolishly) turned in their weapons effectively left the black community without the means for its protection. Thus, Memphis' black community found itself particularly vulnerable to another attack.

A renewal of hostilities took place on the May 2, and based on the evidence, there is little doubt that under the guise of restoring order, the second day of rioting was planned and premeditated by the city's (mainly Irish) civil and business leaders. Men like John C. Creighton, judge of the recorder's court, Attorney General William Wallace, and John Pendergrast, the owner of a small grocery store, all had important roles in shaping the course of events that day. Both Creighton and Wallace were seen making speeches in an attempt to evoke deeply entrenched anti-black passions and whip up excitement among members of the posse. Indeed, Wallace was more than merely one of the mob's ringleaders; he also took the extraordinary step of leading the posse to Folsom \& Company's gun store where he proceeded to purchase "thirty or forty doublebarrelled shot-guns [and] ammunition with which the guns were loaded." 52

Similarly, local business leader John Pendergrast also played a major leadership role in the riot. The Pendergrast family in particular used their establishment as a "headquarters" for the various members of the mob. Henry Porter, an African American and also the owner of his own small business, testified that on the morning of the second day of rioting the mob's activities centred around Pendergrast's business. That morning, Porter went to see Pendergrast just hours before the outbreak of the hostilities. Upon his arrival at the Pendergrast's store, Porter witnessed Pendergrast and three other men go into the store to load their pistols. Pendergrast then told Porter that "they were going [to South Memphis] to kill every damn nigger." Porter, naturally fearing for his safety, as well as that of his family and his grocery store, asked Pendergrast whether or not there was any danger of his family being burned out that morning. To this Pendergrast replied: "No; I am the ringleader of the mob this morning and you will not be disturbed. I saved you myself last night." Incredibly, after this exchange, Pendergrast went out to see Porter's mother who shared the same concerns as her son. Pendergrast reassured her that she would not be harmed. Porter's mother, still unconvinced of her safety, pointed out to Pendergrast that he could not possibly be "everywhere the crowd is, and [the mob] might burn down the house while [he] was away." Certain of his ability to ensure her safety, Pendergrast reaffirmed what he had told Porter moments earlier by definitively stating "you should not be hurt." The mob then proceeded to burn African American homes, beginning with a house which was directly across the street from the Pendergrast's store. ${ }^{53}$

Not only does this confirm the extent to which the riot was planned by cer- 


\section{Left History 5.2}

tain "elite" members of the Irish community, it also shows, as Altina L. Walker has argued, that race was not the sole criterion for victimization in the riots. ${ }^{54}$ Those blacks who showed the necessary deference to the city's new power brokers were spared, while those who did not were made to bear the full force of the mob. Indeed, one white bystander referred to the riot as a "well appointed thing which had been planned for a long time," while yet another referred to it as a "kind of hibernian movement." 55

The riot continued well into Wednesday night; the acts of the mob ranged from petty theft and arson (similar to the police department, most of the members of the fire department were Irish - many firemen refused to put out the fires in the black community and indeed even participated in setting these fires) to rape and murder. On Thursday May 3, General Stoneman, finally convinced that the "posse was a riot in itself," decided to step in. On that day, Stoneman issued an official order to the Mayor, City Council, all of the Civil Officers of Shelby County, and the City of Memphis which banned the posse and ordered in the Fourth U.S. Cavalry to restore order. ${ }^{56}$ By the end of the day, there were no further disturbances in Memphis. Many northerners, however, were not convinced the riots were truly over. A small group representing the teachers and clergy of the black community went to see General Stoneman and expressed their fears that a general conflagration would take place and the whole town would be burned down. Several other northerners approached Stoneman and told the General that they feared they would be driven out of the city. Although Stoneman did not share their concerns, he offered them the protection of his troops and free transportation out of the city. ${ }^{57}$ Most took Stoneman up on his offer; it was undoubtedly a fitting end for many who had longed wished that these "nigger loving radicals" would get out of Memphis.

W.E.B DuBois argued that the animosity between the white (often immigrant) working class and African Americans was historically a function of the immigrant labourer's fear of being reduced to the level of slaves by economic competition. The result of these fears, argued DuBois, was the outbreak of race wars in major urban centres like Cincinnati, Philadelphia, and New York. DuBois further maintained that historically the privileges associated with identifying oneself as "white" acted as a kind of "public and psychological wage" which afforded white workers a certain measure of public deference, served to alleviate their anxieties, and supplemented their poor material conditions of their existence.

The benefits white workers accrued from "whiteness," continued DuBois, was evidenced in their social status. White workers were "admitted freely" to public functions with other whites, their votes enabled them to select public officials, policemen were drawn from their cohort, and their children enjoyed 
well funded and "conspicuously placed" schoolhouses which provided their children with a level of instruction far superior to that found in black dominated schools. ${ }^{58}$

However, within the broader context of this narrative of white racial formation among the American working class, the processes through which the Irish in America struggled to assert their claims to whiteness and white supremacy is perhaps the most fascinating due to the well documented and striking similarities between the characteristics ascribed to African Americans and the Irish. Noel Ignatiev points out that the difficulty Irish workers had in claiming the privileges of white workers was the thorny problem of first establishing that they were indeed white at all. Ignatiev, citing Frederick Douglass' mid nineteenth century injunction that "[the Irish] are becoming houseservants, cooks, stewards, waiters, and flunkies. For aught I see they adjust themselves to their stations with all proper humility. If they cannot rise to the dignity of white men, they show they can fall to the degradation of black men," demonstrates that "it was not always clear on which side of the color line [the Irish] fell.".59 David Roediger points out that in antebellum America adjectives such as "lowbrowed," "savage," "bestial," "lazy," "wild," "simian" and "sensual" were used to describe the Irish ${ }^{60}$ Similarly, Dale T. Knobel argues that like African Americans, Irish Catholics in nineteenth century America were considered savage, subhuman, prone to inherent laziness, and lacking in any ability to perform any task efficiently due to an "infection of idleness." In addition, in nineteenth century America, "nature" and "nationality" were closely related in the popular mind. In fact, the two concepts were virtually inseparable in contemporary American discourse. As Knobel states:

\footnotetext{
Americans' perception of what constituted an ethnic group and their perceptions of what seemed to be the most important indicators of ethnicity were channelled by the connection of nationality "character" and changing notions about the seat of "character" itself... These ideas became locked up in ordinary language. ${ }^{61}$
}

The pervasiveness of these antebellum representations of the Irish also become "locked up" in the "ordinary language" within the city of Memphis during Reconstruction. Hence, the historical record suggests the "public deference" and "psychological wage" which DuBois argued was afforded to the white working class as a whole, and as Ignatiev and Roediger argue were a crucial aspect of the terrain upon which the white racial formation among the Irish working class in the antebellum North took shape, were scarcely apparent for the Irish of Memphis.

Perhaps it is this lack of public deference for the Irish, and this groups' only partial access to the compensatory "wages of whiteness" in Reconstruction-era Memphis which led a fair number of contemporary observers of the riot to 
explain the hostilities between the Irish and African Americans in essentially economic terms. ${ }^{62}$ Dr. J.M. Keller articulated this widely held notion when he testified" it is a conceded point that the sons of Erin do not like the sons of Ham, particularly when they come into conflict with their wages." ${ }^{163}$ Reverend Ewing O. Tade expressed similar sentiments when he commented that "the Irish have an intense hatred of the Negroes because they are afraid they will take away their work. They have combinations here now to drive out the coloured draymen and hackmen. The Irish and others, I know, are in league now having regular organizations for the purpose of suppressing coloured labour." ${ }^{44}$

Despite the claims of these observers, while economic competition was an undeniable element of the historic character of African American/Irish hostilities in Memphis and elsewhere, it would be extremely reductionist to attribute this particular outbreak of riot solely to economic conditions created by two materially impoverished groups battling for the meagre resources at the bottom of the economic ladder. When one considers the socioeconomic background of the members of the mob, it becomes clear that the motivations behind the mob's actions were much more complex than a mere response to an economic threat. Few of the participants in the mob were members of the proletariat or lumpenproletariat classes. In reality, a little over 90 per cent of the rioters were from the ranks of privileged workers; 16 percent of the rioters were policemen, 10 percent were firemen, 17 percent were clerks and artisans, 19 percent were grocery saloon keepers, and 28 percent were from the ranks of small entrepreneurs. Only 9 percent of the rioters were labourers. ${ }^{65}$

The vast majority of the rioters then, were members of a new, mainly Irish, "respectable" working class; this status, however, was fragile and tenuous. Most of the rioters were relatively recent arrivals to Memphis. That is to say that the class of Irish involved in the mob were not members of the solid Irish Protestant upper class and middle class that came to Memphis before 1850 . Moreover, by and large the ascendancy of a significant portion of the the rioters to the ranks of the respectable working class status was a relatively new phenomenon. It is also clear, however, that Irish "claims" to the codes and subject positions embodied in discourses of white working class respectability were unstable. Any sense of "respectability" the Irish may have derived from running a shop or donning the uniform of a policeman or a firefighter rested uneasily beside representations of "dissolute" whiteness - the marked, tainted and "Othered" whiteness that marked the place of the Irish in the imagination of the dominant culture - a link that was made more immediate due to the fact that a good number were from the ranks of those very same reviled Irish Catholic labourers who came to the city in the railway boom of the 1850 s. Moreover, their hard fought class status was contingent upon the perpetuation of the composition of the civil government that emerged in postbellum Memphis - and this was particularly true in the case of Irish police officers and firemen. In short, their class position relied almost entirely upon the continuing rule of the Irish "city fathers" in Memphis. 
Many in Memphis, both the so called "better class of citizens" who were generally the older more established property holding and professional AngloSaxon residents of the city, as well as even a few newly freed African American slaves, shared common ideas about Irish "character" and nature. Because it is such an unusually detailed historical source, the Congressional Report can be read as a text that provides us with a small window onto the discursive element of the construction of postbellum racial ideology. More specifically, this particular text reveals the peculiarities of the construction of the Irish [Catholic] subject and racial identity, and hence, the very roots of Irish insecurity and psychocultural angst.

There are several references to the dissolute nature of Irish subjectivity throughout the Congressional report. Two of the more extreme and revealing examples from the report show how Irish whiteness could be called into question by discursively situating the Irish near or within the realm of "blackness." One witness, J.S. Chapin, a Memphis insurance agent, articulated this quite effectively (albeit bluntly) when testified before the Congressional committee that "his impression was that a great deal of the people were indifferent to the rioting, for as some said to me, they did not care which whipped, whether the Irish killed off the niggers, or the niggers killed off the Irish." ${ }^{66}$ The testimony of Dr. Creighton and Ellen Dilts reveals a rare example how the instability and contestability of Irish whiteness could be even played out on the terrain of the Irish body ( $a$ theme I will return to in a discussion of African American views of the Irish). Creighton testified that while in the company of Dr Keller, he examined the gunshot wound of an Irish police officer by the name of John Stevens. Crieghton further testified that Keller remarked "the man [is] an Irishman, and so dirty that you [cannot] tell whether the portion blackened was caused by powder or not." ${ }^{67}$ The representation of an Irish body, blackened to the point where a gunpowder mark is not easily discernible, cannot be easily overlooked. The rhetoric and the imagery employed by Keller here is, in sum, disquietingly evocative of the kinds of eerie and often unintended slippages between (frequently Irish) working class whiteness and blackness - indeed what Eric Lott calls the "fragility of racial boundaries" - most commonly, but not exclusively, associated with white (male) bodies in blackface performances. ${ }^{68}$ Ellen Dilts' testimony is also an injunction which signifies the "marked" status of the Irish body. When asked whether the mob assembled in front of her home was Irish or American, Dilts replied: "They looked like they were all Irish, with kind of red faces, some of them, though, appeared delicate." When asked further the identity of a man she witnessed setting fire to an African American schoolhouse, Dilts responded, "I do not know; he was a man who looked like an Irishman, kind of a red faced man. ${ }^{69}$ Ellen Dilts' testimony shows how the construction of the Irish subject became linked to certain ascribed physical traits and characteristics - in this instance, an explicitly and derogatory reference to "red faces" and an inherent assertion that the Irish, by nature, 
were identifiable due to a quality of "indelicateness." To put it more simply, the implication here is that one could differentiate between the Irish and non-Irish members of the mob based upon who appeared "delicate" and who did not.

The Irish could also be situated near blackness by means of racial "inversion." One example is particularly revealing, in that it shows that one of the keys to understanding the fragility and dissoluteness of Irish whiteness is that it could, at least in some cases, fall under black gazes - even if, in this particular instance, the black gaze was only figurative and imagined. In a fascinating exchange, John Martin, an attorney, was asked "What sort of judge of a good white man is a Negro?" Martin replied that a one could find a "great many intelligent, shrewd negroes, who will judge of a man pretty well." When asked further whether if he were to "have a mayor chosen by the Irish and that class of men who control your elections here, or one chosen by resident negroes; which one do you think you would prefer to trust your life and property under?" Martin responded "I will answer the question frankly but not directly. [...] I am very anxious," he said, "that the negro should be entrusted, under proper limitations, with elective franchise." Moreover, in his view "a large portion of the negro population here...would vote very intelligently and understandingly with quite as much understanding, and probably more that some of our white men entitled to the franchise." The unease with which Martin answered this question is palpable, and indeed understandable, as he was clearly walking a rhetorical tight-rope - wishing not to outright condemn the notion of African American (male) enfranchisement while attempting to stress, as subtly as he could, that granting a white male prerogative such as the franchise to blacks should, of course, have limits. While Martin's painfully constructed answer points to the highly charged political atmosphere within which these Congressional hearings took place, the equivocalness of Martin's answer is less important than the distinction between good and bad white men - a crude but telling "bifurcation of whiteness" - and the idea that a government chosen by bad white men could embody corruption, incivility, moral decay, and disorder, and that blacks could hold bad whites under scrutiny.

Somewhat less startling examples of the contestability of Irish whiteness can be found in other testimony. J.S. Chapin provides an example of how ideas surrounding Irish socioeconomic class, character, and nationality became conflated in popular discourse. In response to the question of the class and nationality of the members of the mob, Chapin definitively answered, "I think those I saw were, without exception, Irishmen." According to Chapin, the "better class of citizens" (merchants, businessmen and property holders) were not a part of the mob. Chapin was then asked whether those involved in the riot were usually employed in draying, hauling and driving hacks or employed upon the wharf. To this Chaplin responded "partly that class and partly the frequenters and those found around the saloon; the class of idle men I shall call loafers." ${ }^{.70}$ Clearly, Chapin's preconceived notions of Irish "character" made him oblivious to the 
fact that only a very small number of the rioters were labourers. His less than flattering description of the rioters as a group of "idle loafers" is perhaps most telling of just how deeply embedded negative stereotypes of the Irish were in the minds of native born Americans, and how easily these pervasive representations could obscure reality.

Notions of "respectability" were also an integral part of the construction of the Irish subject in the discourse that permeated postbellum Memphis. In the minds of most of the older residents of the city, Memphis had been taken over by a group that they perceived to be inherently inferior, dissolute, and lacking in any moral fibre. The Irish were thus seen as an affront to the "respectable" long standing residents of the city that had been barred from the corridors of power due to their political disenfranchisement.

Robert White, a doctor who had recently moved from Iowa, testified "it is well known that our present police, as a body, is exceedingly poor. It is made up mostly of the poorer sort of Irish, whose prejudices against the Negro are very strong." He went on to state further that he did not "believe that the better class of citizens knew of or had anything to do with the riot in its inception." When Dr. White was asked whether there was, in his belief, a "public sentiment" which was more influential than that of the "better class of people" he responded: "I think that there is a sentiment of that sort among the lower class of Irish and other citizens that would justify almost anything, simply because they do not stop to reflect at all." 71

An even more explicit reference to the perceived lack of Irish respectability could be found in the testimony of Dr. William F. Irwin, another Memphis physician, who stated bluntly: "[ $t]$ he voice of respectable people has not been heard; [t]he elections have all been controlled by the Irish."72 J.M. Chandler, Memphis businessman and editor of the Memphis Post, stated that in his view, none among the participants in the mob could be "classed among our quiet, respectable citizens." Rather, maintained Chandler, the riot was the work of "low rabble" and "men...of a low description."73 Attorney Barbour Lewis, testified that in his opinion, the control of Memphis' affairs and election of the city fathers were to a very considerable degree "thrown into the hands of the Irish who did not participate in the rebellion...and...recklessly take any oath to serve their purpose." ${ }^{\prime 74}$ Ira Stanbrough, owner of a cotton mill, lamented that the city of Memphis had "gone from succession to a lower position - to be governed by an Irish mob."75 John Moller, proprietor of his own small grocery business, expressed a similar opinion of those he labelled as "low-lived Irish rascals" when he indignantly declared, "these watchmen here (policemen) are nothing more than a set of lawless thieves; [t]he whole city government is Irish and about the same character." ${ }^{76}$ Reverend Ewing O. Tade (whose testimony is also cited above), when asked to give to the commission the name of one of the rioters who had spoken before the mob replied that he could not definitively identify the person in question, but commented that, "I think that I would know him 
if I were to see him; he was rather well dressed and rather up for that class of people." 77

The more "respectable" white residents of Memphis, however, were not the only group to express a sense of moral indignation at the Irish communities' lack of respectability, the same, in can be argued, could well have been true among African Americans. Admittedly, only limited evidence of this exists as most African Americans who testified before the committee had more immediate concerns than their white counterparts; most hoped to reclaim stolen property, and a considerable number also recounted rather horrific stories of personal violence. However, it is clear from a rather few exemplary examples of African American testimony that do exist in the report, that some African Americans may well have had the same views on the dissoluteness of Irish character and whiteness as members of the dominant culture. And, indeed, though it must have been hurtful for the Irish to endure the overwhelmingly negative attitudes that the Anglo-Saxon residents of Memphis held toward them, in the case of the hated African American, this must have been patently intolerable. Even Memphis' African American community - a group comprised of members who were, for the most part, just delivered from the bonds of slavery - seemed to hold the belief that they were morally and ethically superior to the Irish.

A few white observers intimated their views on how African Americans saw themselves in relation to the Irish. H.G. Dent, a Memphis real-estate broker shed light on the Memphis black communities' feelings when he stated: "The Negroes have always felt themselves better than the Irish."78 This may have been due to the long history many Memphis blacks shared with elite whites. With an undeniable air of Southern paternalism, a few of the witnesses who testified before the commission maintained that a special relationship - a "decidedly kind and social" 79 feeling in the words of one observer - existed between long standing white residents of Memphis and Memphis blacks which may have also contributed for blacks' sense of superiority towards the Irish. Another white resident of the city testified that African Americans were given preference over the Irish in employment and indeed that blacks, due to their shared history with certain Memphis whites, were "the class that [were] still employed almost altogether." 80

In any case, whether African Americans in Memphis derived their sense of moral superiority by internalizing the dominant cultures' views on Irish character, whether this feeling came from a sense that a shared history with former masters ("respectable citizens of Memphis") conveyed a certain status upon them, or whether a combination of both, the sources allude to the fact that in the eyes of most of Memphis' blacks, the Irish were not their equals and were no where near worthy of the kind of deference that some continued to show their former masters.

A glimpse of these attitudes among African Americans can be found in the testimony of ex-slave Jack Harris Walker. When asked how the coloured people 
were treated during the riots, Harris responded, "[t]hey were treated tremendous bad; but it was not by all the white men, only the low class." 81 Similarly, Lovinda Goddell, an African American widow of a murdered drayman, while recounting events which occurred after her husband's death, testified that while attempting to enter a hospital to retrieve his body, a "little low Irishman stepped up and said: 'Aunty, you wait a little while, and I will see if you cannot go in." Similarly, Thomas Bradshaw's testimony also reveals the low regard in which some African Americans may have held the Irish. Moreover, once again, it also points to the Irish body as a site of an unstable and contestable whiteness. Bradshaw was asked to describe the feelings between the "white and colored" population; his response is telling, fascinating, and worth citing at length:

There were Irish draymen and and colored draymen before the war, and the owners of most of the colored draymen were here in the city, and the Irish did not take the same privileges with the colored men at that time that they do now, because they were afraid of their owners, who would take a stick and come out and maul them. The prejudice was pretty much kept down on that account; but it has seemed to grow up from what I have heard; and their seemed to be a prejudice between the soldiers and the policemen. $^{83}$

This testimony reveals, yet again, the fragility of the boundaries which separated blacks and the working class Irish. In particular, the allusion to the Irish body as a site of the same kinds of debilitating and dehumanizing corporal punishments which were often reserved for black bodies is most illuminating.

The most powerful demonstration of African American attitudes toward the Irish, however, can be found in the testimony of ex-slave Prince Moultrie. When posed with the question, "What sort of people are those who despise colored men?" he responded, "They are the low class among the Irish; I think they are about as mean a people as we have got here; you are not safe at night ... I think it was altogether among the low down people." And, finally, and most poignantly, in response to the question of how he regarded an Irishman in relation to himself, he responded, "I think he is very much below me." 84

Thus, in large measure, the Memphis riots must be understood as the psychologically motivated response of a relatively newly arrived immigrant group which had only recently acquired the status of working class respectability, and was still not considered fully American (read white) by either native born American whites or African Americans. As one scholar has observed, the Irish in Memphis wanted to put the reviled Negro in his place and make sure "he learned to treat the Irish like regular white folks." 85 Two incidents encapsulate what was rarely articulated; namely just how 


\section{$50 \quad$ Left History 5.2}

important it was for the Irish to define their desired status in terms of whiteness. Dr. J.N. Sharp, a Memphis surgeon, testified that while in the company of another physician by the name of Dr. McGowan, and while tending to an injured African American, a "burly Irishman came into the door half drunk and walked round this boy two or three times. Said he, 'You damned nigger, what are you doing here? Why are you not out shooting round the corner like the rest of them?'” Dr. McGowan, elaborated Dr. Sharp, said "Let that negro alone, I know him; he is a good boy." The Irishman then turned to Dr. McGowan and "called him a 'low, dirty Yankee,' and said that he was harboring 'damned black scoundrels who were murdering white men." ${ }^{86}$ Similarly, and most strikingly, David Roach, an Irish police officer and one of the chief ringleaders of the mob, was witnessed by ex-slave Hannah Robinson while he organized a posse on the third day of rioting. Roach was heard to have said "Close up, close up; right shoulder shift. This is the white man's day now." ${ }^{87}$

\section{VI}

The interpretation of the 1866 Memphis riots presented here represents a modest attempt to add to an important body of scholarly work which seeks to de-essentialize the concept white racial identity. Like other works, this study of the role of Irish psychocultural angst as a driving force behind the Memphis riots demonstrates that whiteness was, and continues to be, a mutable ideological and discursive terrain of contestation among groups vying for power and privilege in American society. It was in the face of crippling, demoralising and pervasive stereotypes that the Irish of Memphis attempted to assert their humanity (albeit in a profoundly violent form), shore up their fragile status as Americans - white Americans - and make their own demands for white supremacy.

The Memphis riots have been most frequently likened to the New Orleans riots which broke out only twelve weeks later. This is due to the fact that both outbreaks gave the Radical Republicans the ammunition they needed to discredit Presidential Reconstruction policy, and gave them the mandate they needed to move towards a more aggressive approach towards dealing with the South. The most important element of the Republicans renewed agenda was arguably the Reconstruction Act of 1867, which, for the first time, granted black men residing in former Confederate states the franchise.

Despite the oft cited similarities between the New Orleans riot ${ }^{88}$ and the Memphis riot in terms of geography and influence in shaping Reconstructionera politics, perhaps it is time to resist the temptation of making easy comparisons. The prominent role of Irish/African American tensions and the central importance of Irish insecurity, suggests that the events which shook South Memphis in 1866 liken this particular riot more to antebellum incidents in 
Northern cities like Philadelphia, Cincinnati and New York. Indeed, at least one resident of Memphis picked up on this when he astutely observed, "My impression is that there has always been an inherent antipathy between [blacks and the Irish]...[i]t has always been so in New York, and so it is here...except it is here that the Irish rule." 89 In the postbellum era not only was the very definition or essence of "blackness" changed with the abolition of slavery, but so too had the very conception of what it meant to be "white" in America. In other words, at almost the very same time when African Americans in Memphis and elsewhere began to test the limits of their new and precarious freedom, Irish (Catholics) demanded that they be afforded access to the preexisting construct of "white skin" privilege and all the benefits extended to other "respectable" white men. We must continue to explore the relationship between these two developments in various spatial contexts. In a much broader sense, we must continue to give our attention to the issue of how the "white race" was created and recreated at different points in history, how this process has served as an agent of assimilation and Americanisation, and its relationship to the development of racial and ethnic identities of those for whom white skin privilege was, and continues to be, an impossibility.

${ }^{1}$ I would like to thank Franca Iacovetta, Jerry Ginsberg, Michael Wayne, Scott Nelson, Cindy Hahamovitch, Georgina Riel, Heather Walker, members of the Labour Studies Group, and the anonymous reviewers for their helpful comments on draft versions of this article.

${ }^{2}$ Robert M. Fogelson and Richard E. Rubenstien eds., Memphis Riots and Massacres: The Report of the Committee of the House of Representatives made during the First Session, Thirty-Ninth Congress, 1865-1866 (New York 1969), [hereafter, Report], 36.

${ }^{3}$ See Jack D. Holmes, "The Effects of the Memphis Race Riot of 1866" West Tennessee Historical Society Papers, 12 (1958), 58-79; "The Underlying Causes of the Memphis Race Riot of 1866" Tennessee Historical Quarterly, 17 (1959), 195-122; James Gilbert Ryan, "The Memphis Riots of 1866: Terror In a Black Community During Reconstruction” Journal of Negro History, 62 (July, 1977), 243-257; Bobby L. Lovett, "Memphis Riots: White Reaction to Blacks," Tennesee Historical Quarterly, 37 (1979), 9-33; Altina L Walker, "Community Class and Race in the Memphis Race Riot of 1866," Journal of Social History, 18 (1984), 233-246; and Kevin R. Hardwick, 'Your Old Father Abe Lincoln is Dead and Damned': Black Soldiers and the Memphis Race Riot of 1866" Journal of Social History, 27 (Fall, 1993), 109-128.

4 Theoretically, I find what Cornell West calls a "New Gramscian framework" useful for conceptualising how economic, political, cultural, and ideological elements of a society are articulated through various processes at given historical epochs. A NeoGramsican framework avoids the "primacy of class subjects and the bipolar options for class hegemony" found in Gramsci's work, and embraces elements of the postructuralist thought of Derrida and Foucault in so far as it takes up their challenge to the Western enlightenment traditions of objectivity, scientificity, and universality." However, Neo- 


\section{Left History 5.2}

Gramscian methodology and epistemology also seeks to avoid the "discursive reductionist elements" and the "textual idealist tendencies" in postructuralist theory by placing real structural constraints on agents and discourse. For a further discussion see Cornell West, "Marxist Theory and the Specificity of Afro-American Oppression" in Cary Nelson and Lawrence Urbana eds., Marxism and the Interpretation of Culture (Urbana, Il. 1988), 15-33.

5 The emergence of this body of work - generally tagged "whiteness studies" - has constituted a monumental shift in a number of disciplines such as history, cultural studies, and critical race theory. It has done nothing short of place a group that has heretofore been "unmarked," "normative," and hence able to enjoy certain inherent privileges, under the gaze of racialization. "White" bodies, in short, are now being "raced" like never before. This new "epistemological turn" has been crucial in helping us to further our understanding of how the historically constructed category of "whiteness" has evolved over time, the material conditions, social contexts, and discursive/ideological (and juridical) networks of power within which this construct is enmeshed, and the emancipatory possibilities for subaltern peoples when whiteness and the white supremacy which rests upon its legitimacy is thrown up to the light of critical scrutiny. See for example Cheryl I. Harris, "Whiteness as Property" in E. Nathaniel Gates ed., Critical Race Theory: Essays on the Social Construction and Reproduction of "Race" (New York 1997), 1-83; Richard Delgado, ed., Critical Race Theory: The Cutting Edge (Philadelphia 1995). See in particular section XIII entitled "Critical White Studies"; Mike Hill, ed., Whiteness: A Critical Reader (New York 1997); David R. Roediger, The Wages of Whiteness: Race and the Making of the American Working Class (New York 1991). See also Roediger, ed., Towards the Abolition of Whiteness: Essays on Race, Politics, and the American Working Class (New York 1994); James R. Barrett and David Roediger, "Inbetween Peoples: Race, Nationality and the 'New Immigrant' Working Class" Journal of American Ethnic History, 16 (Spring, 1997), 3-44; Bruce Nelson, "Class, Race and Democracy in the CIO: The 'New' Labor History Meets the 'Wages of Whiteness'” International Review of Social History, 41 (1996); Noel Ignatiev, How the Irish Became White (New York 1995); Eric Lott, Love and Theft: Blackface Minstrelsy and the American Working Class (New York 1995); Theodore W. Allen,The Invention of the White Race Volume One: Racial Oppression and Social Control (London 1994) and The Invention of the White Race Volume Two: The Origin of Racial Oppression in Anglo America (New York 1997).

"For two excellent studies which explore the concept of "dissolute" whiteness see, Warren Hedges, "If Uncle Tom Is White Should We Call Him 'Auntie'"? and Annalee Newitz and Matthew Wray, "What Is 'White Trash'? Stereotypes and Economic Conditions in the United States" both in Mike Hill ed., Whiteness: A Critical Reader, $228,170-172$.

${ }^{7}$ I borrow the notion of racial constructs as a "leaky categories" from cultural critic Rinaldo Walcott's ideas about blackness. See chapter 4 of Walcott's Black Like Who? (Toronto 1997), 81-94.

${ }^{8}$ Altina L. Walker, "Community, Class and Race in the Memphis Riot," 233.

${ }^{9}$ Bobby L. Lovett, "Memphis Riots," 9.

${ }^{10}$ Kathleen C. Berkeley, "Like a Plague of Locusts": From an Antebellum Town to a New South City, Memphis, Tennessee, 1850-1880 (New York 1991), 103.

${ }^{11}$ Berlin, Wartime Genesis of Free Labour, 715; Capt. Charles H. Cole to Brig General 
L. Thomas, 20 Oct, 1863; filed with C-26 1863, Letter Received, ser. 360, Colored Troops Division, RG 94 \{B-487\}.

${ }^{12}$ Berlin, Wartime Genesis of Free Labour, 684-85. Excerpt from Chaplain John Eaton Jr. to Lt. Col Jno. A. Rawlins, 29 Apr. 1863, filed with 0-328, Letters Received, ser. 12 , RG 94 \{K-94\}

13 Hardwick, "Your Old Father Abe Lincoln," 110-111.

${ }^{14}$ Ira Berlin, ed., The Black Military Experience, Freedom a Documentary History of Emancipation, 1861-1867 ser. 2 (Cambridge, 1982), 719. Lt. Col. John Foley to Lt. Col. T. Harris, 11 Jan. 1865, filed with Capt. T.A. Walker to Capt. J.S. Lord, 24 Jan. 1865, Unregistered Letters \& Reports Received, ser., 2870, Dist. of West Tenn., RG 393 Pt. 2 No. 183 \{C-2203\}.

${ }^{15}$ lbid.

${ }^{16}$ Ibid.

17 Berkeley, "Like a Plague of Locusts," 107.

${ }^{18}$ Hardwick, "Your Old Father Abe Lincoln," 114-115.

${ }^{19} \mathrm{Ibid}$.

${ }^{20} \mathrm{Ibid}$.

${ }^{21}$ Lovett, "Memphis Riots," 15.

22 Ibid.

${ }^{23}$ Ibid.

${ }^{24}$ Ibid.

${ }^{25}$ Berkeley, "Like a Plague of Locusts," 15.

26 Ibid.

${ }^{27}$ Ibid.

${ }^{28} \mathrm{Ibid}, 14$.

${ }^{29}$ William B. Stanton, "The Irish of Memphis," West Tennessee Historical Society Papers, 4 (1950), 96.

${ }^{30}$ Berkeley, "Like a Plague of Locusts", 33.

${ }^{31}$ Ibid.

${ }^{32}$ Ibid.

${ }^{33}$ Ibid.

${ }^{34}$ Holmes, "The Underlying Causes of the Memphis Race Riot," 198.

${ }^{35}$ Ibid.

${ }^{36}$ Nashville Union and American, 5 May 1866.

${ }^{37}$ Ibid.

${ }^{38}$ Holmes, "Memphis Race Riot of 1866," 199.

${ }^{39}$ Report, Testimony of Ellen Dilts, 63-64.

${ }^{40}$ Lovett, "Memphis Riots," 20.

${ }^{41}$ Ibid.

42 Report, 7.

43 lbid.

${ }^{44}$ Report, Testimony of Maj. Gen. George Stoneman, 50.

${ }^{45}$ Republican Banner, 4 May 1866.

${ }^{46}$ Ibid.

47 Ibid.

${ }^{48}$ Ibid.

${ }^{49}$ Ibid. 


\section{Left History 5.2}

${ }^{50} \mathrm{Ibid}$. Only one of the Aldermen was reported to have taken Park up on his offer to join the posse. While most of the city fathers promptly evacuated the premises and completely disregarded the Mayor's summons, one Alderman - who was planning to run for Mayor in the next election - reluctantly decided to join the posse.

${ }^{51}$ Report, Testimony of Albert Harris, 62.

${ }^{52}$ Report, Freedman's Bureau Commission, 314.

${ }^{53}$ Report, Testimony of Henry Porter, 166-67.

${ }^{54}$ Walker, "Community, Class and Race in the Memphis Riots," 238.

55 Report, Testimony of Henry Porter, 167.

${ }^{56}$ Memphis Daily Post, 4 May 1866.

${ }^{57}$ Report, Testimony of Maj. Gen. Stoneman, 52.

${ }^{58}$ W.E.B. DuBois, Black Reconstruction in America (Philadelphia 1935), 700-701

${ }^{59}$ Ingnatiev, How the Irish Became White, 111. The Frederick Douglass quotation is from Frederick Douglass, The Life and Times of Frederick Douglas; Written By Himself (London 1962), 298-299.

${ }^{60}$ Roediger, The Wages of Whiteness, 133

${ }^{61}$ Dale T. Knobel, Paddy In the Republic: Ethnicity and Nationality in Antebellum America (Middleton,Ct. 1986), 93.

${ }^{62}$ Harper's Weekly, 26 May 1866.

${ }^{63}$ Report, Testimony of J.M Keller, 133.

${ }^{64}$ Report, Testimony of Reverend Ewing O. Tade, 90.

${ }^{65}$ Eleven percent of the rioters were from unknown socio-economic backgrounds; see

Walker, "Community, Class and Race," 237.

${ }^{66}$ Report, Testimony of J.S. Chapin

${ }^{67}$ Report, Testimony of Dr. R.W. Creighton. (emphasis added).

${ }^{68}$ Lott, Love and Theft, 151; For another narrative of the bodily signifiers which engender the slippages between representations of working class whiteness and blackness see also David Roediger "White Looks: Hairy Apes, True Stories, and Limbaugh's Laughs" in Hill ed., Whiteness: A Critical Reader, 37-39. Roediger analyses Eugene O'Neill's 1922 play, The Hairy Ape, which centres on the demise of Yank, a stoker in the hold of an American "ocean-going" ship. Yank is a man, says Roediger, who distains "the hard scrubbing after shifts that other workers view as necessary to avoid acquiring the complexion of a 'piebald nigger."' Yank's personal descent begins upon an encounter with "heiress/social worker" Mildred Douglas, described as "prenaturally white and paler still in the presence of heat" who goes below deck to find a distraction, perhaps even some sign of life. Upon encountering Yank, she faints, due to the "combination of his dirt, his ferocity, his power, and his "gorilla face." Yank, the object of this "look" is also, says Roediger, "most susceptible to the fear of being seen as "a queer kind of baboon you'd find in darkest Africy." Thus begins Yank's demise. He becomes both "nonwhite" and "inhuman," his downward spiral culminating in his agreement with the assertion that he is indeed a "hairy ape." He ultimately winds up in the gorilla cage at the New York City Zoo.

${ }^{69}$ Report, Testimony of Ellen Dilts, 65. (emphasis added).

${ }^{70}$ Report, Testimony of J.S. Chapin, 197.

${ }^{71}$ Report, Testimony of Dr. Robert White, 164.

${ }^{72}$ Report, Testimony of Dr. William F. Irvin, 132.

${ }^{73}$ Report, Testimony of J.L. Chandler, 307. 
${ }^{74}$ Report, Testimony of Barbour Lewis, 242.

${ }^{75}$ Report, Testimony of Ira Stanbrough, 243.

${ }^{76}$ Report, Testimony of John E. Moller. 87.

${ }^{n}$ Report, Testimony of Rev. Ewing O. Tade, 89. (emphasis added).

${ }^{78}$ Report, Testimony of H.D. Dent, 306.

${ }^{79}$ Report, Testimony of Lewis R. Richards, 210.

${ }^{80}$ Report, Testimony of J.S. Chaplain, 192.

${ }^{81}$ Report, Testimony of Jack Harris Walker, 306. (emphasis added).

${ }^{82}$ Report, Testimony of Lovina Goddell, 77. (emphasis added).

${ }^{83}$ Report, Testimony of Thomas Bradshaw, 307.

${ }^{84} \mathrm{Ibid}$.

${ }^{85}$ Lovett, Memphis Riots, 18.

${ }^{86}$ Report, Testimony of Dr. J.N. Sharp, 154-55.

${ }^{87}$ Report, Testimony of Hannah Robinson, 193.

${ }^{88}$ The New Orleans Riot broke out roughtly six weeks after the Memphis Riot. At the level of national politics, both incidents are widely creditited with giving Radical Republicans the ammunituion they needed to implement the second and more radical phase of Reconstruction policy. See, Eric Foner, Reconstruction: America's Unfinished Revolution, 1863-1877 (New York 1984), 271-280. Also: Gilles Vandal, The New Orleans Riot of 1866: Anatomy of a Tragedy (U.S.L.: The Centre for Louisiana Studies) ${ }^{89}$ Report, Testimony of J.S. Chaplain, 193. 